\title{
City Branding - All Smoke, No Fire?
}

\author{
Jørgen Stigel \& Søren FrimanN
}

\begin{abstract}
Successful corporate branding requires that questions related to communication, publicity, and organizational structures are addressed. An uncritical adoption of approaches known from traditional product branding will inevitably give problems as the properties of tangible commodities and services with their relatively concrete dimensions are absent when the main question is one of values.

Furthermore, when the relatively straightforward identification and power structures of corporations and consumers are replaced by the more diversified structures of city government, their populations, and potential visitors, problems seem to multiply in what has become known as city branding.

This analysis of the communicational aspects of two Danish provincial towns' branding efforts examines both their internally and externally directed communication. It demonstrates that an insufficient understanding of - or willingness to face - these differences will inevitably hamper such branding efforts because of the consequential inconsistencies.

Finally, paths to more effective city branding are indicated.
\end{abstract}

Key Words: branding, city branding, market communication, corporate communication, organizational communication, qualitative analysis

\section{Introduction}

The market is expanding. Since the 1980s essential parts of the infrastructure and communication sector of European nation states, such as railways, air transportation, telecommunication, postal services, TV and radio have been subjected to market laws. But not only is the market spreading into more and more fields; the thinking, the conventions and entire vocabulary and conceptual world underlying marketing and market communication are also gaining ground. It is symptomatic, for instance, that for every new edition, one of the central textbooks of the field, Philip Kotler's Marketing Management, views the conception of marketing and developments of the field in new derived or extended connections. The central functional and symbolic category in marketing, viz. the brand (and branding) is being applied in new ways that would have been unthinkable 20 years ago. The corporate branding phenomenon is a vivid example in this respect, as modes of thought and conceptualisations from branding and marketing are being transferred to organisations and their symbolic and communicative manifestation. This application also subsumes their 'inner life' or 'identity' and the values that are being propounded. In a manner similar to the branding of consumer products, organisations 
are being shaped, or designed, in linguistic and symbolic processes with its members, in a process in which its values, and thus the particular values of their members are being determined. The shaping of meaning and enactment in speech, and the accompanying processes thus become crucial in several ways in relation to corporate branding.

Below we shall investigate concepts such as brand, branding and corporate branding, and their associated value representation. Our aim is to examine what happens when a brand and the underlying corporate brand reasoning is extended to a field such as cities, in a so-called city branding. This will be done by a text and communication analysis of central textual and, to a lesser extent, visual manifestations of the branding activities of two Danish municipalities in North Jutland, viz. Aalborg and Hjørring, such as the activities are expressed in the two brochures which they have published as part of their branding, and also as first moves in relation to their inhabitants. The objective of our analyses are fourfold in that they will study: i) the way that the texts address their readers, and how they inscribe them in their project by activating them in the cause (including, obviously, the text as a sender or enunciation instantiation; ii) the designed slogan and its meaning(s); iii) the implementation and the representation of special (brand) values asserting the uniqueness of the locality; iv) the overall textual expression in regard to its inward and outward directionality. Some will say our method is discourse analytical, others that it is text and communication analytical, but this is inconsequential as our aim is to more specifically study partly how the texts handle some of the central problems in corporate brand thinking, especially with regard to its processually oriented dimensions: a) their formulation of identity and value determination must largely be based on a consensus among the interested parties. How is this brought about when a city is involved?, and b) the brand and branding activities are aimed at the organisation's surrounding world while the process takes its point of departure in an entirely different world; viz. in the enspeechment of actors' and interested parties within the organisation. How is it ensured that already existing conceptions and images, which may be crucial for the further communicative strategy, are taken into account? In sum, one might say that this paper and the underlying study pose the question: To what extent is it possible to apply the (corporate) branding philosophy where cities and towns are concerned?

\section{Brand \& Branding}

The brand and the branding activity are not necessarily the same. The concept of branding is thus a later and rather recent arrival which is inspired by some of the characteristics and advantages of a brand, but it focuses primarily on the process and the activity itself in relation to establishing, maintaining and extending a brand - and, it should be noted, it does this in particular on the basis of ideas about a company's or an organisation's particular identity. Brand and branding are absolutely essential concepts in marketing and market communication. Based on Kotler (1984) and Aaker (1996), we shall below give brief definitions of cultural concepts within the field.

A brand is a registered trademark, designated $®$. It protects and indicates a company's ownership to a named, particularly identifiable product (brand and branding derive from the branding of cattle in order to establish ownership). The identifiability derives from the specially designed packaging, the name or logo, slogan, and other distinctive traits, which distinguish the trademark from both its product category, and from other, competing brands. The trademark simply aims at lifting the product out of its 
product category, which is often designated as the generic product, in order that it may become the expected brand. If the branding process results in a (perceived) improvement of the product (making it the extended brand), then the goal will be to maintain its acquired and unique position. It may thus become the ultimate brand, privileged by customers as the only choice.

As distinct from the concept of the trademark product, the brand or branded product designates what the consumer transforms the trademark into when purchasing, consuming and living with it.

The trademark, or branded product offers a number of functional dimensions as well as rational, visible advantages, among which could be mentioned: i) a guaranteed price (according to lists), homogeneity in volume and quality, durability, excellent performance, servicing and replacement, the right to make complaints to the trademark holder, and ii) the ability to effect or achieve something, e.g. solve a problem ("Er De udkørt k1. 3? Medova The") ${ }^{1}$ (see expected brand above). Thus an important feature of the branded product is that the consumer can address the manufacturer, company or originator, rather than be left to the good-will of the purchase point. Equally important, the producer is able to address the consumer directly without being dependent on the distributor or vendor's willingness to act as a mediator. The interest created in consumers by marketing activities works as a pressure on vendors.

Thus, an important feature of a trademark's branding activities is not only identity creation through the name, but also through differentiation, i.e. a clear distinctiveness vis-à-vis other brands and the entire product category. This may be achieved through a number of parameters, e.g. in the form of pledges to honour special expectations ("Forvent dig lidt mere af os."; "Lidt bedre end andre gode oste."; "Probably the best beer in the world." $)^{2}$

All of the above factors contribute to the creation of forms of personification of a company's products and, in addition, of the company itself (e.g. "Just do it." and "We're loving it."

As pointed out above, in the interaction with the consumer or buyer, the trademark transforms into a brand: in the consumer's mind a distinct image or association is made or attributed to the brand. The brand holds a cognitive-emotional dimension, which to some degree causes the consumer to identify himself and his consumption with it and makes him view the brand, himself and his behaviour in the light of a special material/ immaterial meaning ascription to that brand. Put in categorical terms, one could say the brand occupies a mental territory, while the product or trademark merely occupies a functional territory.

In the very last instance, the brand is an intangible, symbolic, and physically nonexisting entity. In other words, the tangible product may become a secondary thing in relation to the intangible and symbolic product, as in H.C. Andersen's The Emperor's New Suit. The brand thus carries with it values, bondings and loyalisations in relation to the consumer. As a result, holders of branded products are extremely interested in the relation between their intended value ascription to the brand (the brand identity) and the brand image, i.e. the consumers' conception of and his attitudes to the brand, and in how this matches and reflects the consumers' need for (self)expression, identity and values. Ratings are also made of brand awareness, i.e. how easily the brand comes to the consumer's mind. Measurements of brand position are also made, reflecting the brand's position in relation to other brands along a number of parameters and values, including in which fields it possesses particular advantages. This is all summed up in a brand 
personality; i.e. the traits that enable the consumer to immediately relate to the brand as if to some old acquaintance possessing a number of exemplary qualities: i) sincerity; ii) excitement; iii) competence; iv) sophistication; and v) ruggedness. Everything is summed up in the broader and more general brand value, i.e. the cognitive representations of central values and abstract goals that the consumer is demanding, such as it may be seen in e.g. LEGO brand values: a) creativity; b) imagination; c) learning; d) fun, e) quality - ethically, with regard to both the product, and trust. In conclusion, a measure of brand loyalty is obtained, expressing the sum of the consumers' experiences with the brand, particularly in relation to its use.

In a historical perspective, the branding approach has primarily pertained to product branding, i.e. the branding of individual products, possibly trailing an already existing brand - also known as extension-line branding (e.g. Ajax cleaning materials). A large number of companies are still operating in this fashion; Proctor \& Gamble is a case in point, backing a large number of trademarks in cosmetics, cleaning materials and detergents. They have thus become a house of brands, and product branding typically affects only marketing as such, and thus involves only the marketing department of the company. This makes branding a question that is primarily concerned with the company's public relations activities.

However, corporate branding, i.e. branding of the company itself, has recently become more widespread, making it a branded house. The philosophy is to turn the company into a brand on the basis particularly of its internal organisational features, i.e. its distinguishing values with respect to employees and their qualification and competences; among these could be mentioned the particular methods and concepts used by the company.

Corporate branding thus becomes extremely interesting to service and knowledge based firms as the company itself moves into focus as the carrier of identity, rather than individual products. It goes without saying that this branding activity will affect the whole management, the company strategy and organisation, not least its employees. Not only the company mission, but its entire vision, culture and values become central elements in the branding. As is the case with LEGO, communication of an aesthetically pleasing 'universe' can attract, appeal and capture the customer by its inherent qualities. Earlier the Danish furniture factory Fritz Hansen did not appear publicly as the manufacturer of Arne Jacobsen's well-known designs the Swan, the Egg, the Ant, etc., but via its corporate branding as The Republic of Fritz Hansen, the company has moved from an almost anonymous position as manufacturer into taking the position of a guarantor of the coveted design.

The reasoning seems to be that it is possible to make the firm into a brand by expressing its special identity and the special values for which it stands, making these the basis of the entire communication effort towards all interested parties, i.e. not only in relation to customers. This would construct a unified framework for all company communication, something that may be a great advantage where the homogeneity of the signals communicated by the company and its employees is concerned. It may also be instrumental in the process of creating an intra-organisational consciousness of its mission, value basis, etc. as this would presuppose an ability within the company of 'finding' its own identity and its specific, unique values - and further that a credible, and thus durable, consensus on what these are can be created among employees. Although establishing the former may be hard enough, especially the latter aspect tends to prove very 
difficult for corporations operating in a turbulent market where constant and increasingly costly readjustments are necessary.

It should be noted, though, that corporate branding is a reaction to changing market conditions as the entire project is aimed at establishing the company's values as its guiding principles, and thus strengthen it in relation to both the swings and trends of the market and to the inner and outer worlds of the company, ensuring a safe anchoring to an organisation-internal fastening point. In this perspective, corporate branding makes sense as an attempt to achieve a steadfast basis, and mitigate the heaves and swings of the changing trends in market communication. But in order for this foundation to be operational, the values that are marshalled out as cornerstones are in risk of becoming watered down to the point of meaninglessness.

Nevertheless, branding is infectious, directly influencing the organisational level and the relationship between internal and external communication. It is now transferred to the personal level as personal branding, and it is contended that it is transferable to other, extremely complicated, demographic units, such as cities and towns. Thus, increasingly wider fields of activity are being subsumed under market communication thinking.

\section{City Branding}

Ever since the topographical literature of the $17^{\text {th }}$ century, Danish towns have sought to attract attention to their special qualities and assets (Christensen, 2005:14). The first Danish advertising strategy with this target was launched in 1932 by Randers in Jutland. It was marketed by the slogan "Randers - hvor Søvejen møder 13 Landeveje" 3 (Jensen, 2002:14). This spurred several other Danish towns and cities to start campaigns and invent slogans of their own, such as "København - Nordens Paris". ${ }^{4}$ Since then, by far the majority of towns have published tourist brochures and promotional films, presenting their assets in text and image - in a manner that has demonstrated little variation. Most Danish towns have a town arms that illustrate its characteristics. Often the arms can be traced back to the medieval period, since when it has in effect served as the town logo. The marketing of towns is by no means a novel idea.

Cities and locations are increasingly being marketed as 'trademarks' along the lines known from numerous intensive and extremely costly company and product branding campaigns (Mollerup, 1995; Olins, 1999; Schulz and Hatch, 2000). This is done by using concepts such as 'Nation Branding', 'Region Branding', 'Destination Branding' and 'City Branding' (Morgan et al., 2002:4). As is generally observed in relation to branding, city branding creates a snowball effect, putting cities without a brand under pressure to develop one:

The mere fact that place ratings about the attractiveness of places for residents, tourists and investors are more and more common makes it difficult for politicians and public authorities not to join the brandwagon (Langer, 2001:7).

The branding of cities and places takes various forms. New York City is branded with the slogan "The world's second home", Bilbao exploits Gehry's Guggenheim museum, whereas India "changes you", Aalborg is "vild med Verden', and Hjørring is simply "a brand". Further examples of Danish towns are Horsens, which emphasises it musical and cultural efforts, while Slagelse tries to capitalise on its position in team handball. 
Proponents of 'City Branding' (e.g. Morgan et al., 2002; Christgau and Jacobsen, 2004) argue that the concept of branding can be more or less directly transferred to city marketing. From the perspective of marketing logics, a city can, metaphorically speaking, be seen as a 'business', and the advantages boasted by the city as its 'products'. They are for sale to internal as well as external target groups on a 'glocal' market where cities compete to burn themselves into the customers' memories - and to burn a hole in the wallet of same. As most cities have quite similar services and infrastructures to offer their visitors, the contest is about creating a 'unique position' distinguishing one city from the next, so that customers are attracted. The city is metaphorically viewed as an organisation with an internal management of its 'members', the management acting in accordance with the city brand values so that they are kept happy and give good publicity for the 'organisation', acting as 'ambassadors' for the city (Christgau and Jacobsen, 2004:41). A town is furthermore seen as a 'person', to whom an 'identity' is ascribed, a 'core', or 'soul', or a 'mentality' with a set of stable values. In this perspective, the city is given ontological status as a 'personality' with identity and values. Those values are assumed to be open to internal exploration and ultimate condensation into an 'identity', which can be applied in the internal or external marketing of the city as a brand. The concept of identity has long been a contested and problematic issue within developmental and personality psychology (Erikson, 1971). The problem is that a person's identity is dynamic and subject to constant change. Furthermore, identity will vary in relation to the social context and the situation in which an individual interacts. For these reasons, it would be more appropriate to speak of identities. The problem is not lessened when the identity concept is transferred to a city with its variegated gathering of individuals, groupings, institutions and businesses. The identity of a city is an abstract construct that cuts away concrete differences and contrasts while presupposing constancy and consensus. Below an example is given of how the mentalities and dominant lifestyles of the cities of Århus, Aalborg and Odense are interpreted on the basis of a compass analysis (see note 5 by Gallup). The segmental analysis resembles measurements on the position of a brand in relation to other brands. It should be noted, though, that a segmental analysis captures lifestyles whereas brand position measures one brand in relation to other brands.

\section{Examples of Values in Århus, Aalborg and Odense}

Gallup's compass analysis divides cities into segments according to their prevalent lifestyles and mentalities. This is a result of combining two axes: a) the modern vs. the traditional, and b) the community-orientated vs. the individual-orientated.

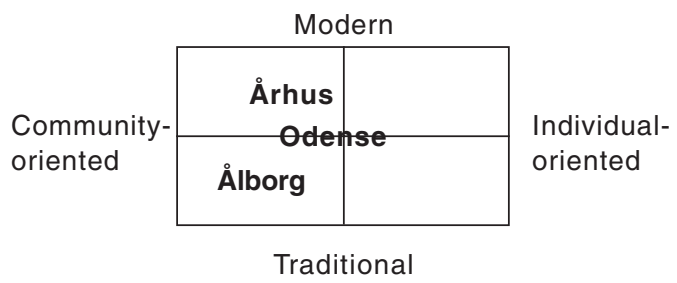

Source: Duus, 2003:38. 
On the basis of this analysis Duus (2003:37) noted significant differences between the three cities. The citizens of Århus are primarily modern and community-orientated in their values, reflecting a creative mentality, which is seen in their modern taste in clothing, their cafés and outdoor life, cultural activities and ethnic phenomena of various kinds (Duus, 2003:39). In contrast, the citizens of Aalborg were found to exhibit traditional and community-orientated values as reflected in the city's rough and ready businessmindedness:

In Aalborg they do business - in the broadest sense of the word (...) Wherever you turn, a bargain is thrown at you. It's a "what's-the-price? culture" in the extreme form. (...) But this is where the popular strain becomes apparent. More action, more movement, more shouting (literally and as attested by the thousands of advertisement boards in front of shops and cafés); the city has this feel of the bargain, exercising its mercenary character with great pride. This is (private) enterprise - rough and ready (Duus, 2003:39, our translation).

Odense's values are characterised as average for Denmark, which makes the city inconspicuous. Duus describes it as "white-collarish, i.e. nice, neat, soft-spoken and middleof-the-road" (Ibid.:39). ${ }^{5}$

\section{City Branding: Internal and External Levels}

A major point in the branding literature is that a correspondence must exist between externally presented brand values and internally experienced values, i.e. the marketing should reflect both the citizens' conception of their city and what visitors experience (Christgau and Jacobsen, 2004:26). If this connection between the internal and the external level is not established, there is a great risk that the campaign will consist of rather lofty values and concepts that are incongruent with what can be experienced by citizens and visitors alike.

City branding thus comes down to uncovering and defining an 'identity' that can form the basis of communication to both internal and external target groups - be they citizens, customers, businesses, tourists, commuters, or potential newcomers, etc. The fact that these target groups are so diverse poses a presentation problem, as it is impossible to communicate effectively to several target groups at the same time. On the other hand, separate marketing for each target group is very costly. In general, cities have small marketing budgets in comparison with businesses. Japanese Sony spent a total of approximately \$300,000,000 in 1997 while the entire membership of the World Tourism Organization had a similar amount at disposal for the same year (Morgan et al., 2002:13).

Proponents of city branding are usually aware that the product or organisation metaphor may not be completely valid. In general they make the reservation that cities are characterised by greater complexity and diversity than organisations, but that a comparison is nevertheless defensible (Ibid.:5). In spite of this concession, brand boards attempt to create a consensus on a city's identity as the basis for its marketing. Critics object that it is futile to market cities as trademarks as they are not conceived as brands by the public. Furthermore, there is a crucial difference between cities and organisations as the former do not have the same possibilities of regulation and sanctioning in relation to their citizens as do organisations in relation to their employees. Therefore, citizen behaviour and communication cannot be directed, managed or streamlined. In contrast to 
organisations, cities have a much larger number of interested parties, and hence, conflicts of interest need to be taken into account before any consensus on identity and basic values can be reached, if at all.

\section{City Branding: Globalisation and Experience Economy}

According to marketing logic cities should be presented as products to be sold on a global market with fierce competition to attract customers, be it via the Internet or other media. An important part of the argumentation for city branding derives from the perspectives of globalisation and the experience economy (Pine and Gilmore, 1999; Zukin, 2003:10-19). One of the arguments is that cities with a brand can win market shares from cities without a brand - with depopulation and economic decline as a consequence. However, the problem with cities is that is difficult to delimit marketable 'articles', and the way in which they are consumed (Kotler et al., 1993). The branding of cities and places is thus concerned with creating and profiling a commodity from something that is fundamentally intangible.

The experience economy has changed the focus of our economy away from its traditional emphasis on articles, industry and production to an economy in which consumers are willing to pay an extra price for products and services that hold qualities, feelings, values, meanings, identity and aesthetics. This is achieved by a collaboration of the cultural sector and the business communities in an effort to create experiences in relation to the products (Pine and Gilmour, 1999; The Danish Government, 2003). In this perspective, the branding of cities aims at:

(...) organising items in such a way that connections are created between entities as diverse as products, resources, values and strategies. (...) Places are no longer left to history, but are integrated in comprehensive strategies for how culture, trade, infra-structure and architecture, among other things, can be combined (Pedersen, 2005:15, our translation).

The aim of such extensive branding strategies is the construction, staging and communication of the city as a space for unique experiences that are saleable on a global market. Tourism organisations strive to market cities and places as 'tourist trademarks' making the tourist's choice of holiday destination a lifestyle indicator with high emotional appeal or 'celebrity' value. Furthermore, when the tourist has returned home, the destination may have value as a topic of conversation (Morgan et al., 2002). Souvenirs, merchandise, logos and images can be used to signal that you have "been there, done that" to those wishing to notice this.

In commerce and services, the focus is on the competition among the larger towns of Denmark, the aim being to attract customers from the surrounding area and win market shares from competing towns. According to a report by the Retail Institute Scandinavia (2000:12), this is achieved by transforming the city centre into a combined space for experiences and consumption, phenomena that are situated between culture and retail trading. But the problem is that should all major cities transform their city centres into such spaces and erect landmark buildings designed by celebrities such as Koolhaas, Liebeskind, Gehry, or Mau, and brand themselves with slogans, logos and values with accessory merchandise pens, caps, badges, etc., the unique would end up becoming the standard, with little overall effect. This appears to be the general problem in branding. 


\section{Branding Hjørring}

In June 2001, the city council of Hjørring decided to invite two advertising agencies to present proposals for a marketing plan for Hjørring, to be ready for the opening of a new stretch of motorway in the autumn of 2002. In August 2001 Dafolo Marketing A/S was chosen for the task, for which a total of DKR 750,000 was allocated. In January 2002 a public hearing was held, with contributions from the local business council, the chamber of commerce, the tourist association and Hjørring's city council. A few months later, the branding campaign was launched, comprising a web site, a 'profile' brochure and accompanying manual, a TV spot, which was aired over a period of time on a regional commercial TV station. Furthermore, the council opened a brand shop selling various merchandise with the Hjørring logo printed on it. The campaign was primarily directed at the town's own citizens, with the aim of making them 'ambassadors' of their home town. But beyond that the campaign had the objective of marketing Hjørring, both nationally and internationally. Based on the printed profile brochure, we present an analysis of its slogan and values, and their predication.

\section{The Slogan}

The slogan is found at the bottom of the front page, with six images placed above it, illustrating the values chosen as exemplary for Hjørring. To the left of the slogan, the logo is shown in a square in the bottom right corner.

Usually a slogan gives a condensed expression of the symbolic values emphasising the assets of a product or a company in relation to the consumer, e.g. its qualities, price, status, use value, newsworthiness, etc., as for example in: "Nokia. Connecting people.", "You meet the nicest people on a Honda.", or "Small Wonder - Volkswagen." Aesthetical, rhetorical and stylistic effects borrowed from the lyrical register, such as rhyme, rhythm, alliteration, metaphors and puns are often used, e.g. "M\&M melt in your mouth, not in your hand.", "Hvem ka', Bilka.", etc. ${ }^{6}$

Hjørring's slogan, "Hjørring som mærkevare - Disse er ordene", ${ }^{7}$ defies convention in that it neither expresses the merits of the place are, nor uses stylistic effects. It directly addresses the receiver with a straightforward message that Hjørring is to become a brand, the implicit meaning of "these are the words" being that no more needs to be said, which could be paraphrased in the words; "We know it may sound strange, but let's put it straight: 'This is about branding Hjørring - and that's it."' In this way the sender can be said to have made allowance for the possibility that some citizens of Hjørring would regard the branding endeavour as rather odd.

The conjunction 'as' ('som') establishes a property or role relation between the two units: "Hjørring in the capacity/role of a branded product." In the utterance an equation is established, in which Hjørring is defined and categorised as a brand. In choosing the word a distinction is likewise made from the way in which makes or brands are traditionally marketed, which frequently takes the form of "company or product name + asset/value/quality', as in "Seat - autoemoción" - or vice versa: "Lev livet friskere. Lev med Macs." In Hjørring's slogan no value is ascribed to the name. The word brand is a hyperonomy, i.e. an abstract superordinate whose subordinate instantiations are numerous: Coca-Cola, Audi, Levis, Dockers, Ray Ban, etc. This broad and abstract classification renders the meaning diffuse and void, as it is not made clear what is actually meant by brand. The word is also used as a technical term in the branding literature 
(Olins 1994; Mollerup, 1995), in which great importance is attached to it in relation to the positioning of a product or an organisation in the market. Therefore, the word could also be analysed as an intertextual reference to branding theory. Viewed from this angle, it would be a question of internal communication among professionals who wish to make Hjørring into a brand. This would in effect obstruct communication with citizens and external target groups for whom the concept of brand has no meaning (as they would hardly know the terminology). To those target groups the first part of the slogan would at best appear as a 'clever' piece of rhetoric, at worst it would fail to give any meaning at all. The second part of the slogan, "These are the words", in no way contributes to elucidating meaning or message, as it merely consist in a meta-communicative reference to the preceding words. The phrase is known from oral interaction as a frame marker signalling the conclusion of a longer stream of speech.

'[T]hese' refers anaphorically to the words previously used; the function of the demonstrative pronoun usually being to ensure cohesion or point out an internal relationship between units of meaning in a text. In this specific case, however, the pronoun does not refer to the meaning of the preceding sentence as this was merely a meta-communicative reference to the words of the preceding sentence. Thus the last part of the slogan creates the tautology: "the words are the words" (i.e. $\mathrm{X}=\mathrm{X}$ ), which only makes sense if the implicit meanings are analysed.

\section{Litotes}

When the slogan is regarded as part of the general style of the material, it can be interpreted as an instance of litotes, i.e. an understatement, often used humorously. In the profile brochure (Hjørring Municipality, 2002a: pp.6-7) this variety of humour is exemplified by a picture of the ballad-singing critic of Danish and North Jutland hypocrisy and staidness Niels Hausgaard with a caption that describes the local sense of humour as "our favourite understated kind of humour". It appears that litotes is the prevalent style code in the brochure, as is illustrated with a reference to one of the performer's songs: "Niels Hausgaard is spot on when his lyrical alter ego punctures his neighbour's Mrs Hyacinth-like attempts at keeping up appearances." The inhabitants of Hjørring are attributed with modesty, and understatement is seen as their favourite mode of expression - characteristics which are also used in the material, the profile brochure thus reflects the mentality. Even if the slogan, on a first reading, were to be interpreted as an instance of litotes, this would not add any other meaning to it than that invoked by yet another use of the figure - albeit one unlikely to provoke a smile. In addition, as litotes is not yet established as a style code, the reader is unable to draw on this humorous frame in the first reading. The figure is first used on p. 5 in the brand board's rather lengthy introduction to the campaign, where the colloquial turn of phrase "These are the words" recur to signal the conclusion.

\section{The Logo}

The logo is placed in extension of the slogan on the front page of the brochure. It consists of the proper noun Hjørring in a white type on a background of a square black field, resembling a film negative.

The font used is a simple sans serif with soft wavy lines, reminiscent of Art Nouveau fonts connoting the 'artistic', 'aesthetics' and 'quality'. In particular, the last two letters, 
$n g$, the modified o $(\phi)$, and the two $r$ s are unconventional, the soft curves of $n$ and $g$ being connected. An unequivocal interpretation of this feature is not possible because of the abstract symbolic code. Does the bottom part of the $g$ resemble a hook? Or could $n g$ symbolise a person with the dot on the $g$ as a nose, or perhaps a Viking symbol? The soft and exuberantly curving form may also allude to the ingenious, the frisky or the cunningly artful. The rounded lines form a contrast to the squarely functional expression in the streamlined letters $H, j$ and $i$. The Hjorrin? slash of the $\phi$ does not go all the way but ends midway into the letter, creating a centreperiphery symbolism that may cause the reader to associate to a board with a dart in the bull's eye. As Hjørring is the theme, the $\phi$ could symbolise the town as a centre in relation to a periphery delimited by the circle, thus setting apart the town centre from the surrounding area, but no more so than that the slash indicates the possibility of travelling between the two spaces. This centre-periphery symbolism illustrates a contrasting relationship, or an antonymy between such pairs as 'inside-outside', 'town-country', 'culture-nature', which is echoed in the choice of the logo colouring displaying a light centre and dark periphery. The text takes up the same theme, with a clear delineation of the centre to Hjørring, while the outer limit of the periphery is left semantically undefined. The text thus describes the periphery vaguely as a space reaching from Hjørring's vicinities to the entire Europe.

If not a capital, Hjørring is an extremely important centre in Vendsyssel (p. 11). Centrally located at the crossroads between Sweden, Norway and Denmark, Hjørring has a direct link to the European motorway net (...). As a European metropolis, Hjørring offers first performances of films in the new cinema centre (Hjørring Municipality, 2002a:2, our translations).

Litotes are used rhetorically to play down the status of the town by the use of negation and reservations such as "If not a capital, (...)". At the same time the figure is exploited in exaggeration and boasting within the frames of negation and reservation by which the meaning is implied or presupposed. Ordinarily Hjørring is not regarded as a capital of anything, but rather as a provincial town in the Danish periphery.

In the logo the two $r$ s show a reversed picture of each other, indicating a likeness to the logo of Hjem-Is, a door-to-door distributor of ice-cream products, although the mirrored image is hardly intended as symbol of an ice-cream cone. As the marketing campaign was scheduled for the opening of the new motorway, the idea suggests itself that the $r$ s stand for the sliproads. They might also resemble two upraised, open arms expressing openness and accommodativeness.

A determination of the logo's meanings is presented in the brand manual:

Depending on who the beholder is, it may give rise to associations to a variety of things: culture, nature, the past, an aspiring movement, open possibilities, a motorway, between two seas, the centre (Hjørring Municipality, 2002b:10).

The Hjørring logo is intended to function as a brand, "a unifying graphical symbol" (Ibid.:3), ensuring uniformity and direction in all communication within the framework 
of the brand values. The abstract symbolism of the logo, which does not communicate a clear message in an unequivocal symbolic code, may easily cause the receiver to overlook the intended message. In fact, it is not unlikely that the receiver will ascribe unintended meanings, and associate to similar logos, such as the one discussed.

The logo was exposed at all bus stops and on police vehicles. Citizens showing the logo on their cars also participated in a competition to win a drive-yourself holiday with a local travel agency.

\section{Value Statements}

Work on the values to be associated with Hjørring was begun after the launching of the logo. According to the website each member of the brand board ${ }^{9}$ contributed ideas for the values that best describe Hjørring and set it apart from its competitors. After several meetings and brainstorms the board unanimously selected six values on which to concentrate. No surveys were conducted on citizens' views in this regard, something that might have ensured that the ideas or values chosen actually reflected those of the citizens of Hjørring. A risk therefore existed that the campaign would not reach or appeal to its initial target group, the approximately 35,500 inhabitants of the municipality.

The profile brochure (Hjørring Municipality, 2002a) presents each value with a picture taking up two thirds of the page. Below the image the value is given in bold in a centred headline. Then follows an elaboration expounded in six lines of body text in which several meanings are ascribed to each value, as shown in condensed form below. The general style code used is litotes.

\begin{tabular}{|c|c|c|c|}
\hline $\begin{array}{l}\text { Value } \\
\text { statement }\end{array}$ & Backing & Form and content & Antonym ${ }^{10}$ \\
\hline $\begin{array}{l}\text { Understa- } \\
\text { ted } \\
\text { humour }\end{array}$ & $\begin{array}{l}\text { Mentality is a function of } \\
\text { locality, background and } \\
\text { region (Montesquieu) }{ }^{11}\end{array}$ & $\begin{array}{l}\text { Assertions on solidarity, humour and } \\
\text { modesty."Our downplayed humour can be } \\
\text { found nowhere else", "Proud to be so damn } \\
\text { modest" }\end{array}$ & $\begin{array}{l}\text { Frigidity in social } \\
\text { relations, stuck- } \\
\text { up } \\
\text { Copenhageners }\end{array}$ \\
\hline Original & $\begin{array}{l}\text { Mentality is a function of } \\
\text { locality, history and natural } \\
\text { conditions(Montesquieu) }\end{array}$ & $\begin{array}{l}\text { Assertions on originality, and openness."We } \\
\text { are not like the others; "embracing } \\
\text { hospitality" }\end{array}$ & $\begin{array}{l}\text { Ordinary, un - } \\
\text { original, petty } \\
\text { bourgeois }\end{array}$ \\
\hline $\begin{array}{l}\text { Mini- } \\
\text { metropolis }\end{array}$ & $\begin{array}{l}\text { Historically, its size and } \\
\text { geographical position has } \\
\text { placed Hjørring at the centre } \\
\text { of Scandinavia and Europe }\end{array}$ & $\begin{array}{l}\text { Exaggerations on size and centrality."If not } \\
\text { a capital, then an extremely important } \\
\text { centre"; "at the crossroads between } \\
\text { Sweden, Norway and Denmark"; "European } \\
\text { metropolis" }\end{array}$ & $\begin{array}{l}\text { Capital, metro- } \\
\text { polis, provincial } \\
\text { town, } \\
\text { provincialism }\end{array}$ \\
\hline $\begin{array}{l}\text { Variety in } \\
\text { assets }\end{array}$ & $\begin{array}{l}\text { Variety in choice is an } \\
\text { advantage }\end{array}$ & $\begin{array}{l}\text { Assertions on the town's wealth of } \\
\text { opportunities."The countryside and the } \\
\text { cultural activities (...) offer an unusual } \\
\text { variety of opportunities." }\end{array}$ & $\begin{array}{l}\text { Harmony, } \\
\text { uniformity }\end{array}$ \\
\hline Closeness & $\begin{array}{l}\text { Physical proximity leads to } \\
\text { social closeness and } \\
\text { humaneness }\end{array}$ & $\begin{array}{l}\text { Assertions on physical and social } \\
\text { closeness."In Hjørring you're close to } \\
\text { everything"'You will get closer to the people } \\
\text { around you, your fellow citizens, your family } \\
\text { - and yourself." }\end{array}$ & $\begin{array}{l}\text { Physical and } \\
\text { social } \\
\text { distance,big city } \\
\text { individualism }\end{array}$ \\
\hline Natural & $\begin{array}{l}\text { Mentality is a function of } \\
\text { nature and locality } \\
\text { (Montesquieu) }\end{array}$ & $\begin{array}{l}\text { Assertions on the topography's influence on } \\
\text { the mentality. "The wealth of unspoiled } \\
\text { countryside and beautiful scenery in and } \\
\text { around Hjørring has an impact on the } \\
\text { people who live here"'The healthy and } \\
\text { natural can be felt in both sentiment and } \\
\text { manner." }\end{array}$ & $\begin{array}{l}\text { Artificial } \\
\text { unhealthy } \\
\text { unnatural } \\
\text { stressful }\end{array}$ \\
\hline
\end{tabular}


The described values may be condensed into two themes:

1) The mentality of citizens, emphasising emotional and social merits.

2) The town's facilities, emphasising functional, physical and practical assets.

What is striking about the survey is that the lexical choices, be it in headlines or text body, maintain such an abstract and general level that they give neither a unique nor a specific characterisation of the town and its inhabitants. The description of their mentality expresses general human traits, values, wants and needs such as closeness, sagacity, sincerity, authenticity, etc. The understated humour does not set Hjørring apart from other places, but is a feature that popular wisdom ascribes to Jutes in contrast to Copenhageners. Neither are Hjørring's facilities unique. There is nothing extraordinary in provincial towns offering green spaces, educational institutions, commerce, business, cultural activities and easy transportation. It also seems to be an exaggeration to speak of the town as a mini-metropolis when considering the provincial scene that can be observed in a visit. Variety is an immanent trait of any town, evident in many areas: social and ethnic groups, associations, institutions, architecture, business, history, etc. Every town has its originals, and is unique in the sense that it is different from all others, so the value of originality is not specific for Hjørring. The assets emphasised for the vicinities are typical of provincial towns of Denmark: woodland, beaches, farming land and opportunities for outdoor activities. Being quite common rather than extraordinary, the values described would thus match most Jutland towns.

The slogan, logo and values presented by Hjørring are a far cry from the great idea of branding theory, which is to position a city as a unique brand with an identity tied to specific mental values, the propagation of which would make ambassadors of its citizens, and make it saleable to the external world as a commodity on a market, thus attracting customers, tourists, businesses, and new taxpayers. The reason that the brochure emphasises the ordinary rather than the specific can probably be found in the broad composition of the brand board and the thankless task of shaping an identity that might make "the town speak with one voice - across the local council, trade and industry, tourism and educational institutions" (Ibid.:3). According to the process description at www.hjoerringbranding.dk, far more than a hundred candidates for value statements were reduces to six. The choice was presumably made on the basis of the principle of the lowest common denominator so that the selected values were those general, commonplace statements about which the board was able to create a consensus. The result seems to be that the extraordinary and contradictory was jettisoned along the way. The tendency to strive for consensus is also apparent in the enunciation structures of the communication circuit of sender and receiver.

\section{Enunciation - We, We, and We}

The most prevalent form of address in the profile brochure is we, the first person plural form of the personal pronoun. It is used in both an exclusive sense; "the editorial or authoritative we", and in an inclusive sense; "the collective we" (Allan et al., 1995:147).

The second person singular personal pronoun, you, is less used. Directly addressing the reader is used as a strategy to achieve closeness, which mimics face-to-face communication in this context.

Quite aptly, this is exemplified in the discussion of the value 'closeness': 
In Hjørring closeness also means that you will get closer to the people around you, your fellow citizens, your family - and yourself' (Hjørring Municipality, 2002a:15, underlining added, our translation).

In the brochure, we is used much more frequently in the collective than in the editorial sense. Below, we shall see examples of both uses.

\section{The editorial we - exclusive use}

We shall try to say it in a few words (p. 5).

We have deliberately tried to find words that appeal to common sense, and (...) to the feelings (p. 5).

We hope that the campaign, with this publication (...) (p. 25).

(...) we have cut to the bone. We now have a clear picture of the values that reflect Hjørring (...) (p. 29).

\section{The collective we - inclusive use}

We all know what Hjørring stands for ... or do we? (p. 3).

(...) nobody is as damn proud of their own modesty as we are (p. 6).

We are not like the others - we are something special - and we' re proud of it (p. 9).

(...) we have a lot to offer - and a lot of different things at that (p. 13).

We are surrounded by fields (...). We all live with nature (p. 17).

Speaking in all modesty - we actually have good reason to boast about our town and municipality (p. 29).

The editorial we is only found in the preface and epilogue to the profile brochure, in which the brand board collectively addresses its readers concerning the intensions and aims of the brochure and campaign. The use of the collective we is the general, most frequent form of address. The collective we, which includes the sender $(I)$, the receiver (you), and the citizens of the municipality (all of us), thus indicates a deictic borderline (Dik, 1989:38) to a they that does not belong to Hjørring. Rhetorically the use of the collective we functions as a persuasion strategy intended to make the receiver endorse the attitudes, values and qualities emphasised by the sender in order that the receiver adopt his entire perspective and point of view in relation to Hjørring municipality.

\section{The Profile Brochure and the Context}

Persuasiveness in a text presupposes that words, sentences and images are relevant, have news value and broadly reflect the receiver's mental conceptions and is in accordance with the context. As our analysis of the profile brochure has demonstrated, the slogan, logo and text express what is general and shared rather that what is unique and specific to Hjørring, with the result that the content has no real value or relevance for the target group. The stylistic use of litotes frequently lapses into exaggeration, as when Hjørring is characterised as a "capital", "European metropolis", or "powerhouse". Such epithets hardly reflect the inhabitant's conceptions, or the impression that one forms from observation. Without jumping to conclusions, it therefore seems justified to conjecture that such expressions will be regarded as 'hot air', i.e. part of a 'clever' advertising stunt that tries to play up the town to more than is justified. 


\section{Branding Aalborg}

The branding process in Aalborg was commenced in 2004. Following a competition the task was given to Dafolo, who were also responsible for Hjørring's campaign. Aalborg ${ }^{12}$ also set up a brand board consisting of representatives from the local authorities and relevant commercial and institutional interests.

At the time of time writing (spring 2005) the accessible material consisted of a brochure, in which Aalborg's four central values and their vision is presented in text and image, a

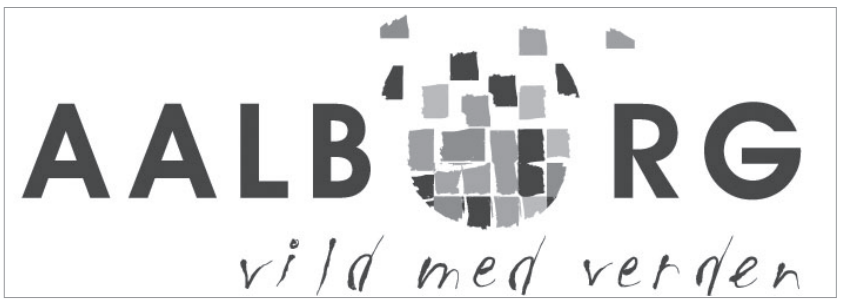
corresponding website dedicated to Branding Aalborg with short video sequences, and an activity plan for the coming two years. It appears from the plan that a series of 'scenario meetings' or 'future workshops' will be held, and that businesses and corporations are to be given a central role as spearheads for the project. For their use, "a toolbox will be presented, enabling the companies to use Aalborg's values, visions, film and logo in the branding of their own businesses and Aalborg". In other words, the idea is that Aalborg businesses, or rather their employees, will be instrumental in the branding process, and that the branding of the company and the city is envisaged as a concerted effort for which the toolbox is intended. Its contents have not yet been disclosed, but it will presumably not be very different from Hjørring's.

As of now, the brochure (with the website) makes up the essential material that presents Aalborg's values and vision. The main predication is established on the front page by the slogan: "Aalborg - vild med verden." ${ }^{13}$ This is identical to the logo, which consists of the name of the city printed in capital letters, with the $o$ slightly enlarged, making it resemble a globe made up of multicoloured, slightly irregular squares in red, green, black, blue and orange, the topmost of which are on their way up into the universe. The logo thus gives an illustration of the statement's predicate, "crazy about the world", whose form gives an impression of a delicate but unruly handwriting. Dynamic forces seem to be at play; the globe or 'the world' is inscribed in 'Aalborg' in the shape of something that is 'on the move', and overall, an impression is given of the slightly wild and unruly, or even frisky and sparkling. For example, the copybook writing would not achieve a high mark from a school teacher (with its rightwards slant, for one thing), but it seems that the whole point is to strike a new chord.

While the graphic design of the slogan, which also functions as the logo, underlines and reinforces the content, the question is how the predication should be understood in a branding perspective. Is states explicitly that Aalborg, whose collective identity or 'personality' is to be accepted at face value, is crazy about everything outside the city itself. In a figurative sense, this can be understood to mean that Aalborg has a mind to tasting life, being extrovert and dynamic. This may be read as a statement that this city, as opposed to other cities, is not self-sufficient but sees itself in interplay with the surrounding world. Its identity is defined by its connectedness and attention to the (outside) world, rather than anything specific about itself. As opposed to e.g. Århus, it is not a "city of smiles". In other words, what is both attractive and peculiar is that the essential characteristics of Aalborg do not reside in the city itself, but in its extrovertedness as it is expressed in its interacting with the outside world; in the fact that the city is reaching out of itself, being oriented towards the surrounding world rather than towards 
itself. In this way something is said about the 'outgoing' qualities of the city, and perhaps also about a certain unprovincial mentality, but very little about the city itself. In saying that you are 'crazy' about someone or something, you are likewise saying that your identity, behaviour, or entire being, is guided by this other entity rather than by yourself.

The problem of fleshing out the identity crops up again in the text body, which is mainly found on the right hand opening of the brochure, while the left is taken up by a mosaic of high-quality photographs of various Aalborg motives.

In what may be called an introduction, "Aalborg - værdier og vision" ${ }^{14}$, we are told that:

Aalborg has no equal anywhere. Thanks to our geographical position, our history and natural resources, we have come to be who we are - for better or for worse. Mostly for the better, if we may say so. And why shouldn't we? We are not like people in Århus, Odense or Copenhagen - which is OK with us.// We are different in a number of ways, having a mentality of our own, a special way of looking at the world. By means of a number of natural gifts and traditional values, we have developed our own distinctive character - and we intend to cultivate it together (Branding Aalborg, 2004: p.5, our translations).

This introduction to what is subsequently treated as Aalborg's distinctive features gives an indication of what will prove to be one of the brochure's characteristic problems. The slogan, "Aalborg - we're crazy about the world", could be seen as a forewarning of this. On the one hand the brochure speaks on behalf of someone while on the other hand it addresses the same group with claims characterising them, using argumentative and hortative language. This takes the form of a construction that slides from Aalborg to ours, repeatedly enforced by our, we and us into which the reader, who is presumed to live in Aalborg, is clearly sought to be inscribed. At the same time, it appears that the text is not clear on its we; the most glaring example of this confusion is witnessed in the conclusion where it is asserted that "we have developed our own distinctive character", followed by "we intend to cultivate that together." Here the use of we clearly demonstrates its limitations - if not a breakdown, in that the first we is the one that the text without further ado - claims to share with its readers, and with which the reader may, at least partly, be assumed to consent. The next we is somewhat different in that it seems intent on actively doing something. This is the brochure's authoritative we, which now, quite abruptly, introduces itself with an intent to "cultivate our distinctive character" in a community ("together") - but with whom? The answer is presumably: with those with whom the text has already contended to form an unproblematic communality. The we that was previously addressed has now, all of a sudden, become a plural you. As we saw with Hjørring, a clash between the collective we and the editorial we becomes apparent. But whereas in Hjørring's case there seems to be a carefree alternation between the two, it is significant that here the breakdown happens only once. It will be seen later why this does not necessarily stem from the writer's incompetence, but rather from the problematic equivocality inherent in the purpose of the project from which the text takes its point of departure.

It is noteworthy that nothing substantial is said about the special merits of the our and the we. The initial sentence is a pure platitude, and even Montesquieu would have had reservations about the contention that his philosophy could explain why Aalborg should be different from three other Danish cities. The text's construction of a we as against a 
they hinges on this theory, but no indication as to what the differences might be is supplied. Their insubstantiality is apparently compensated for in the ensuing chopped-out sentence fragments. But the chiselled linguistic form, which emphasises each individual piece of information, contributes little of substance to the content. The chanting intonation adds merely to the formal aspects while giving no hint of factual information on the alleged differences.

Thus far the reader has been told no more than "we are not like the rest - we are something special". From a rhetorical point of view, the statement may be intended to set the mood for what follows.

Without further introduction the text goes on in a rather authoritative tone to establish that "[t]he special assets of Aalborg can be summarised in four values", viz. "Contrasts, A broad outlook, Cooperation, Drive". Here it is spelled out what the we vows to collaborate on. In what may be an attempt to mitigate the authoritarian tone a more disarming chord is struck in the ensuing short-cadenced and chiselled-out sentence fragments at the top of page 7 (Ibid.):

First and foremost, Aalborg is the people who live here. This is manifested in what each of us thinks and does in our everyday lives - and in our view of each other and the world around us - our dreams and habits - our whole attitude to life. // Aalborg supplies the physical frame - offering a rich choice of spaces giving us great opportunities for activity.

It appears that the text deems it necessary to reinstate the presupposed communal, or collective, we in extremely forceful repetitions of we and our, with a number of truisms added. The fleetingly introduced editorial and authoritative we is thus quickly and forcefully eradicated.

The problem is that the text assuredly grants itself the authority to inscribe the reader into a general we and speak both to and on behalf of this presupposed instance that has been established in contrast to certain others. But it soon becomes clear that the text cannot consistently assume this position. A we instance which expresses an underlying will or intention crops up here and there. This duplicity is presumably tied to the fact that the text cannot or will not appear before the reader using an explicit you, something which would make it apparent that the reader was seen as someone with a distinct role to play. This works seamlessly to a certain point, e.g. where general statements with no indication of action are concerned, but once the statements express a will or indicate action, the trick of inscribing the reader collapses and the attempt to speak on his behalf is revealed as unwarranted, clumsy and patronising.

The inscription of the reader in a we is closely connected to the tacitly assumed sympathy from the readers, which is taken so much for granted that nothing substantial about Aalborg seems to require explicitation. No reader is allowed to contradict or show offence at the straightforwardly assumed authoritarianism in the text's all-embracing confessional enunciation of its statements. The assumed reader appears to be one who was born and bred in Aalborg, and a local patriot. This seems rather peculiar, not only in relation to the slogan, but also when considering that the text is intended to motivate and engage readers in relation to players who cannot be assumed to share background or beliefs with the text. In other words, they may not be part of the 'congregation', to use a word that comes to mind in reading the brochure. The word is used not only to polemicise, but as will be shown, the text as a whole is reminiscent of the communication used by a preacher in front of the congregation. 


\section{Values and Vision}

Aalborg's four values (see table below) are established by emphasising a number of assets and via positive (self)predication ("We are ..."). They are structured according to certain underlying argumentation schema or types. They further exhibit certain stylistic characteristics.

\begin{tabular}{|l|l|l|l|}
\hline $\begin{array}{l}\text { Value } \\
\text { statement }\end{array}$ & Backing & Form and content & Antonym ${ }^{15}$ \\
\hline Contrast & $\begin{array}{l}\text { Having many choices is an } \\
\text { asset }\end{array}$ & $\begin{array}{l}\text { Having your cake and eating it too - with } \\
\text { respect to choices on where to live and } \\
\text { work }\end{array}$ & $\begin{array}{l}\text { Harmony } \\
\text { Uniformity } \\
\text { Dreariness }\end{array}$ \\
\hline $\begin{array}{l}\text { A broad } \\
\text { outlook }\end{array}$ & $\begin{array}{l}\text { Mentality is a function of } \\
\text { locality and landscape. } \\
\text { Topographical basis } \rightarrow \\
\text { mental basis (Montesquieu) }\end{array}$ & $\begin{array}{l}\text { Assertions on openness, authenticity, } \\
\text { straightforwardness, unceremoniousness. } \\
\text { Genial breaches of style: "You just say } \\
\text { what's on your mind"; “He/she's one of us" }\end{array}$ & $\begin{array}{l}\text { Petit bourgeois } \\
\text { provincial } \\
\text { restrictedness } \\
\text { Bigotry }\end{array}$ \\
\hline Cooperation & $\begin{array}{l}\text { External opposition and } \\
\text { adaptation processes result } \\
\text { in interdependence and } \\
\text { solidarity ("let's show 'em") }\end{array}$ & $\begin{array}{l}\text { Contrasting of: Conjured professions of } \\
\text { belief in "cooperation" and "serious } \\
\text { antagonisms between segments of the } \\
\text { population", "cold individualism"',"those few } \\
\text { who only care about themselves" }\end{array}$ & $\begin{array}{l}\text { Strife Selfishness } \\
\text { Factionalism }\end{array}$ \\
\hline Drive & $\begin{array}{l}\text { Unbroken historical chain } \\
\text { back to the Vikings and } \\
\text { other enterprising heroes }\end{array}$ & $\begin{array}{l}\text { Accumulation of historical moments which } \\
\text { are contrasted to "but we don't make a fuss } \\
\text { about it" }\end{array}$ & $\begin{array}{l}\text { Passivity } \\
\text { Stagnation }\end{array}$ \\
\hline
\end{tabular}

This raises the question whether contrasts in themselves can express values. It is apparent that what is described are rather some contended contrasting qualities or assets, be it with regard to nature or the landscape, the urban space, cultural activities or in relation to transportation or business, such as in: "Right there, close to everything, is the Limfjord, which is Denmark's only real river system. You can live by the sea, the fjord, or in the woods, and still work in the city - or vice versa - and have no more than a 20 minutes' ride" (p. 9). The 'contrasts' turn out to represent choices and diversity rather than real alternatives. Everything can be had: both city life and landscapes, both gentle and tough, both "the roaring North Sea" and "the genial East Coast", "cobbled streets" and "characteristic industrial monuments", "peaceful oases" and "hectic night life", "city buzz" and "rural atmosphere", "fine arts" and "subculture", "grand opera performances" and "fringe theatre", both "down to earth, ready for a bargain" and "groundbreaking and international perspective" (p. 9). To call the Limfjord a proper "river system", let alone "Denmark's only real river system" can only be characterised as disingenuous or going over the top in the attempt to dress up Aalborg as more exotic than most other provincial towns situated in a Danish fjord.

'A broad outlook' is easier to understand as a value when the expression is read as an image of tolerance and broadmindedness. Once again, it is the natural geography with its "open spaces and wider horizons" which is called upon to supply the basis of arguing for a characteristic asset. Likewise, reference is made to the position by "the river", which "has given us so many foreign impulses, promoting openness and unpretentiousness of mind. We have never had a problem with identifying ourselves with those qualities, as we Aalborg people are genuine and straightforward." As we saw above, the text speaks not only on behalf of an indubitable communal we, but also on behalf of an external instance: "Everyone who has visited Aalborg will testify that from the minute you arrive, you're 'one of us"” (p. 9). 
While the two previously considered values are deeply anchored in nature and geography, which are also contended to be transformable into a certain mentality, the value 'cooperation' exhibits a glide towards a contrast, e.g. by implying that Aalborg has been neglected in national politics: “'We're in this together" expresses a typical local attitude; likewise "If we want something, we have to make it happens ourselves". The implication is that whereas Aalborg has had to rely on its own resources, other cities have just opened their mouths to let the plums fall. Another contrast is emphasised by stating that "historically, there were always serious antagonisms between segments of the population", but this is contended to demonstrate a strength in that "we [have] seen the value of teamwork", so that "Aalborg's transition from an industrial to an information society has been exemplary", which leads to a profession that "we swear by teamwork" (p.13).

The final value for discussion is 'vigour', or 'drive' ${ }^{16}$. A connection to the past is created when it is contended that "[o]ur history carries the stamp of enterprising people who were not afraid of meeting the world, and who understood how to make the best of the town's position by the river". Characterisations such as "Vikings", "leading commercial town in the Nordic region", "biggest provincial town of Jutland, surpassed only by Copenhagen", "we quickly saw" the possibilities in exploiting raw materials are all listed as historically defining moments on a par with the present-day accumulation of high-tech, information technology and space research activities in Aalborg. Also "the biggest carnival in Northern Europe", the Tall Ships Race and a notorious Jean Michel Jarre concert are thrown in for good measure. None of this is "merely coincidental", but "we don't make a fuss about what we do - we just do it" (p.15). Modesty is claimed as a deed - the long list notwithstanding.

In the vision the four values and a number of the essential words are repeated in a new context of utterances of volition ("we will/want to") and are now being contrasted to the big city as a concept:

Aalborg wants to be an antipole to the traditional big city. Bigger of heart, lesser of size - and with higher to the sky.// We want to cultivate the contrasts and create a space for diversity. Seize the world. And through cooperation and initiative secure the frames for a life in development" (p.17). ${ }^{17}$

This is subsequently turned into a form of support for being "crazy about the world" which is justified by contending:

"That we are open and tolerant and prefer cooperation to cold individualism. That we are alert and internationally orientated. That "local" and "global" for us has always rhymed. The world begins in front of our noses (...). We are crazy about the world in Aalborg - we've always been.// The world is a wide and wonderful concept. At once small and incredibly big. Just round the corner and behind the far horizons. (...) The world is yours. And the world is mine. We are all world citizens. That we will make use of (pp.19-21). ${ }^{18}$

As we saw in the introductory paragraphs the text occupies the reader's domain by the patronising embrace in which a breakdown between the editorial/authoritative we and the collective we becomes apparent. A rather pompous lyrical loop about the concept of "the world" is repeated. The trumps are played with a number of high-flown, chiselled pleas, such as "Let's show the world (...); Let's welcome (...); Let's paint the town red (...)", ending on the almost disconnected: "To give a voice to all those who have a message. To disregard those few who only care about themselves." The preaching manner is reinforced by the final condemnation of possible dissidents and black sheep. 
As pointed out earlier, features typical of congregational communication recur: the invocation of the congregation, the creed of faith, the indication of a communal fate and mission (in casu, the world), the conjuring exhortations to symbolic action, and the final excommunication and denial of Satan.

\section{City Branding Vanishing in Smoke?}

The brochure's text is to be read as a first move in an extended process. As such its task is to act as an inspiring catalyst for players in the branding process. This is evident also in the final calls for action. One of the main problems inherent in the text lies in its sweeping presupposition of the reader as an already sympathetic instance on which it may count in its inscription of the textual we, as seen in the contentions about us and our. This problematic position encounters problems when it comes to authoritarian statements on what has apparently been established (one might ask by whom) as the true values shared by everyone in Aalborg. The other major problem concerns a more precise definition of the substance of Aalborg's character. What is termed as contrasts turn out to be something rather different, viz. the variety offered by a city that, in a popular phrase, has 'a bit of everything - and enough for everyone'. But this is something that could in principle be found in so many other places. Also where variety is an essential value, there will be many contenders. 'A broad outlook' is based on the natural resources, and may seem a more pertinent value, but it is rather problematic in that no argumentation or evidence is offered. Neither is credibility supported by the provincialsounding platitudes about visitors ("one of us"). On the whole, the text appears to have difficulty with mentioning anything truly original for Aalborg.

On the one hand, the overall problem is that the chosen form of address transgresses the boundaries of the reader's domain by its inscription of him and her as indubitably sympathetic towards the enterprise. This is what we have termed congregational communication, and it soon reveals its own shortcomings. On the other hand, the authoritarian fashion turns out not to posit anything substantial when the values are spelled out. They seem to fizzle away into platitudes, and, perhaps revealingly, conclude in explicitly naming certain high-profiled events, some of which are likely to be recalled as rainsoaked and ill-planned fiascos, others that cannot truly be credited to Aalborg (e.g. the Tall Ships Race).

In short, the problem is that difficulties are bound to occur in the attempt to 'enspeech' or 'invent' values for a city with the intention of inscribing 'everybody' into them, because commonplaces will inevitably carry the day when support has to be mustered from almost all internal parties. This is generally the Achilles' heel of corporate branding, but the weakness is exacerbated when a unit as complex as a city is involved. 'The lowest common denominator' will be used, even more than when a corporation or an organisation is involved. The result may appear well-meant, but the remarkable and catchy will elude the branding effort when things are seen from the insider's perspective which obscures the outsider's fresh outlook on the city. Being "crazy about the world" may in itself be a sympathetic attitude, but when seen from the outside, it will probably appear as rather uninteresting: "Who and what are you - and what can you do?"

"I'm the one who is crazy about the world!"

"Oh, that's interesting to hear, but what am I supposed to do about your desires - and why are you entertaining me with that? Tell me something about what you can do, and what is special about you!" 


\section{Conclusion: Cities in the Perspective of (corporate) Branding}

In this paper we have repeatedly suggested that it may be problematic to transfer the corporate branding philosophy to cities. A major problem lies in the belief that it is possible to uncover the special identity or mentality of a city. This assumption appears to be practically inevitable, being a deeply-rooted part of a traditional mode of thought going back to the patriotic culture of education of the mid- $18^{\text {th }}$ century, in particular as formulated by Montesquieu (1689-1755) and Herder (1744-1803).

The notion is that landscape, geography and climate, etc. shape the mentality of the population, thus explaining why the national characters of Danes and Italians differ, or why Copenhageners have a different mentality from that of people from Århus and Aalborg. This conception forms the basis on which both Hjørring and Aalborg's branding materials rest, but the urban society of the (late) modernist era has struck a blow to ideas linking nature and mentality. Modern man is characterised by mobility, typically moving from place to place in the pursuit of individual goals and desires, rather than staying in one place. Consequently, the conception of a 'popular character formed by nature' does no longer hold true for present-day cities that are changing from a traditional industrial economy to the experience economy typical of the information age. The traditional mode of thought, as based on the sketched philosophies is thus no longer applicable to city-marketing efforts in relation to external target groups. For both Hjørring and Aalborg, the endeavours we have witnessed in regard to finding specific differences in mentality or identity have led to the exact opposite of what was intended, mainly because the formulation of an identity/mentality rests on the assumption that consensus can be reached. A more fruitful and less contradictory approach to the marketing of a city would involve a complete dismissal of the identity conception, in order to clear the stage for working on the creation of a specific profile in city marketing.

A city is a complex organisation made up of a large number of political, cultural, institutional and economic groupings, each with their own interests. This makes consensus on identity a serious problem for brand boards and their advertising agencies as they run a very real risk that it can be reached on only the most general and therefore most nondescript values. This leads to a contradiction in relation to the principal aim in branding a city, which is to emphasise its uniqueness. Furthermore, the problem in city branding (and branding as such) is that as more and more cities are being branded, the special will turn into the ordinary.

In our analyses the abovementioned problems are evident in both Hjørring 's and Aalborg's profile brochures, particularly in the presentation of the logos, slogans and values, and in the chosen forms of address. Aalborg's logo and slogan attempt to create an identity in which focus is directed away from Aalborg with the consequence that they say very little about the city, whereas Hjørring 's logo shroud the symbolic meaning in an abstract graphical code the intention of which only a few will be able to decipher. The slogan claims that Hjørring is a brand while it says nothing in particular about what makes Hjørring a distinct place or about its assets and identity. Our study has demonstrated that the values of both Aalborg and Hjørring were formulated in general, abstract and vague language with little concretisation of any specific or unique values. The values might apply to almost any other city or town in Denmark. The attempts at formulating the essence of what characterises Aalborg and Hjørring present a major problem in the analysed materials in that nothing noteworthy is being said. Another major problem is constituted by the forms of address. In the materials from Hjørring a clear distinction is made between a collective we and an editorial we repre- 
senting an authoritative sender instance appearing in the preface and epilogue in which the brand board collectively addresses the reader concerning the intentions behind the materials. The collective we appears in particular in the description of those general values which we have demonstrated to be void of meaning. They contribute to a rhetorical strategy aiming at persuading the reader into endorsing the project, thereby overcoming any bad will against the project. The Hjørring materials reveal more clearly and explicitly that someone is being spoken to by some others - and thus that contradiction is possible. Branding Aalborg seeks to evade any form of dissent by consistently speaking in a tone of communal confession, as in and to a sympathetic congregation. The enunciation concludes in highly strung, but extremely general-sounding hortations. In either case, it is peculiar to see that discussion or dialogue are not encouraged to a higher degree, something which is bound to egg on the receiver to contradiction, i.e. precisely the opposite of what was intended.

In conclusion it seems that in being transferred to cities the branding concept is bound to encounter opposition as it reinforces some of the contradictions inherent in corporate branding. The first contradiction stems from the fact that cities can neither control the processes leading to the building of the brand, nor ensure that consensus is reached; factors that are necessary conditions for successful corporate branding. Secondly, problems abound in the construction of the values, identity and unique qualities of the city. Unlike corporations, cities cannot claim uniformity in such areas, a fact which leads to truisms and watered-down generalities - clearly because the various parties involved all have their own axes to grind. Lastly there is an unresolved contradiction between this internal perspective and the fact that the branding process has to produce a result that appeals to outsiders. The external perspective is largely absent in the materials; thus, perhaps symptomatically, no image surveys seem to have been conducted. The Achilles' heel of corporate branding is and will always be its obsession with identity, and the belief that once established, it is only of matter of communicating it to the world at large - even when that identity is a rather bland concoction with scant appeal. The response to the problem hinted at in the paper's title must therefore be that, in regard to the analysed materials from both Hjørring and Aalborg, the smoke has so far obscured the fire.

Translation: Morten Berg Olesen

\section{Notes}

1. "Are you exhausted at 3 o'clock? Medova Tea."

2. "Expect a little more from us", "A bit better than other good cheeses."

3. "Randers - where the seaways meet 13 highways."

4. Copenhagen - the Paris of the North.

5. The compass analyses were conducted as quantitative survey studies on a representative section of the population. The subjects were given 42 questions which could be answered by six alternative responses, from 'completely agree' to 'completely disagree'. The assumption underlying the division of the population into segments is that lifestyles and fundamental values can be uncovered by making a rough section through a large number of values, so that individuals, neighbourhoods and nations can be divided into a limited number of categories. The compass analysis has its parallel in sociological segmental analyses such as e.g. the Minerva model (Dahl, 1997) and Douglas' 'Thought Styles' (Douglas, 1996). When a city's 'mentality' and 'identity' has been analysed through a questionnaire survey, the identity is presented as a constant factor, which can be used in the marketing or branding of the city, internally as well as externally. In his examples Duus uses the quantitative analyses as the basis of his interpretation of city identities, mentalities and 'brand essence'. It could be argued that in this, he 
goes well beyond what the data can support. The interpretations are based on his experience of the cities, such as they presented themselves on his visits, and must consequently be viewed as rather subjective.

6. The name of the large discount store chain rhymes with can expressing ability: "Who can - Bilka."

7. "Hjørring as a brand - these are the words."

8. "Live life a little fresher. Live with Macs."

9. To ensure political backing from all interested parties, the board was given a broad composition.

10. Antonyms indicate implicit contrasts to value statements.

11. The conception underlying the idea that the prevalent mentality is a function of, and related to differences in natural environment and climate, has is source in the late natural rights philosophy of the 18th century. In his monumental L'Esprit du Lois (1748) Charles-Louis de Montesquieu (16891755 ) originated this cultural relativistic philosophy. In his writings it functioned primarily as a means of an objectively and scientifically based attack on the absolutist and autocratic rule of the day, and as an argument for republican rule. In its various manifestations the climate theory (e.g. that of Johann G. Herder), had far-reaching effects on the bourgeois revolutions - and henceforth - not least on the rise of the nation states in the 19th century. Over time the popular ideas on specific national identities and characteristics have attained the status of uncontested truisms that are immune to questioning.

12. The municipality of Aalborg in North Jutland has approximately 165,000 inhabitants.

13. "(We're) crazy about the world."

14. "Aalborg - values and vision."

15. Antonyms indicate implicit contrasts to value statements.

16. The Danish term is 'handlekraft', expressing the power to act, with a touch of recklessness.

17. Two central quotes are given in back-translation, i.e. a literal translation, to show their syntactic and lexical style: "Aalborg vil være modpol til den traditionelle storby. Større af hjertet, mindre af omfang - og med højere til himlen.// Vi vil dyrke kontrasterne og skabe rum for mangfoldigheden. Gribe verden. Og gennem samarbejde og handlekraft sikre rammerne for et liv i udvikling."

18. "At vi er åbne og tolerante og foretrækker samarbejde frem for kold individualisme. At vi er fremme i skoen og internationalt orienterede. At "lokal" og "global" for os altid har rimet på hinanden. Verden begynder for næsen af os (....). Vi er vilde med verden i Aalborg - det har vi altid været.// Verden er et vidt og vidunderligt begreb. På én gang lille og ufatteligt stor. Lige om hjørnet og bag fjerne horisonter. (....) Verden er din. Og verden er min. Vi er alle verdensborgere. Det vil vi udnytte sammen.”

\section{References}

Aaker, D.A. (1996) Building Strong Brands. The Free Press.

Allan, R.; Holmes, P. and Lundskær-Nielsen, T. (1995) Danish. A Comprehensive Grammar. London: Routledge.

Branding Aalborg (2004) Aalborg vild med verden. Aalborg.

Christensen, Søren Bitsch (2005) 'Bykonkurrence og byidentitet: Danmark 1960-2000'. Unpublished working paper presented at the 25th convention of Nordic historians (Nordisk Historikermøde), Stockholm University, Session 'Den nordiske staden - från industrialism till postindustrialism', 6 August.

Christgau, Joachim and Jacobsen, Martin Vibe (2004) Byen i oplevelsessamfundet. Unpublished MA dissertation, Copenhagen Business School.

Christgau, Joachim and Jacobsen, Martin Vibe (2005) 'Bybranding i oplevelsessamfundet'. Paper uploaded to www.kommunikationsforum.dk, 7 April.

City Branding. En rapport over de 20 stфrste provinsbyers detailhandelsmassige udviklingsstrategi - vinder-eller taberkurs. Report publisheded by the Retail Institute Scandinavia, 2000.

Dahl, Henrik (1997) Hvis din nabo var en bil - en bog om livsstil. Akademisk Forlag A/S.

Danish Government, The (2003) Danmark i kultur- og oplevelses $\phi$ konomien - 5 nye skridt på vejen. Report, Copenhagen.

Dik, S. C. (1989) The Theory of Functional Grammar; Part 1: The Structure of the Clause. Dordrecht: Foris Publication.

Douglas, M. (1996) Thought Styles. London: Sage Publications.

Duus, J. (2003) Byernes identitet, målgruppe og branding. OPUS-Fyn - Odenses Potentialer, Udfordringer og Styrker. Published by the County of Funen and Odense Municipality, pp. 36-42.

Erikson, E. (1971) Identitet, ungdom og kriser. Copenhagen: Hans Reitzel.

Hjørring Municipality (2002a) Hjørring som markevare. Disse er ordene. Hjørring: Profile brochure.

Hjørring Municipality (2002b) Hjørring som markevare. Disse er ordene. Hjørring: Manual.

Jensen, Tina Knudsen (2002) 'De tretten landeveje', Historisk Aarbog fra Randers Amt, pp. 15-22. 
Kotler, P. (1984) Marketing Management. Englewood Cliffs N.J: Prentice Hall.

Kotler, P.; Haider, D.H. and Rein, I. (1993) Marketing Places. NY: The Free Press.

Langer, Roy (2001) Place Images and Place Marketing. (2001) Copenhagen: Copenhagen Business School (working paper, Vol. 2001-03).

Lash, S. and Urry, J. (1994) 'Accumulating signs', in Economies of Signs and Space. London: Sage.

Morgan N.; Pritchard A. and Pride, R. (2002) Destination Branding - Creating the Unique Proposition. Oxford: Butterworth-Heineman.

Mollerup, Per (1995) Marks of Excellence. A Theory of Trademarks and How They Work. Lund: University of Lund.

Olins, Wally (1994) Corporate Identity. Thames and Hudson.

Pedersen, Søren Buhl; Tangkjær, Christian and Linde-Laursen, Anders (2003) Mellem postkort og politisk strategi - branding af nationer, regioner og byer. Copenhagen: Copenhagen Business School (MPP working paper).

Pedersen, Søren Buhl (2005)'Arkitektur som oplevelses økonomisk forskningsfelt', in LPF Nyhedsbrev, No. 5, Vol. 8. Copenhagen Business School, Institut for Ledelse, Politik og Filosofi.

Pine, B. Joseph and Gilmore, James H. (1999) The Experience Economy. Work is Theatre and Everyday Business is a Stage. Boston: Harvard Business School Press.

Schultz, Majken and Hatch, Mary Jo (2000) 'Scaling the Tower of Babel: Relational Differences between Identity, Image, and Culture in Organizations', in Schultz, M.; Hatch, M.J.; Larsen, M.H. (eds.) The Expressive Organization. Oxford University Press.

Zukin, Sharon (2003) 'Gentænkning af downtown-begrebet. Om branding af det særegne', in Europaiske byer i en global ara. Byidentiteter og regional udvikling - Budskaber og konklusioner. Copenhagen: Miljøministeriet og Landsplanafdelingen, pp. 10-19. 